\title{
Polymerase Proofreading Associated Polyposis
}

National Cancer Institute

\section{Source}

National Cancer Institute. Polymerase Proofreading Associated Polyposis. NCI

Thesaurus. Code C162484.

An autosomal dominant condition caused by mutation(s) in the POLE and/or POLD1 genes, encoding DNA polymerase epsilon catalytic subunit A and DNA polymerase delta catalytic subunit, respectively. It is characterized by colorectal polyposis and a predisposition to colorectal cancer. Mutation(s) in POLE and/or POLD1 genes have been associated with an increased risk of endometrial cancer, breast and brain tumors, and multi-tumor phenotypes. 